\title{
Study on the Small and Middle Enterprises Financing Mode in Financial Crisis
}

\author{
Jingting Ma \\ School of Business Administration, Shenyang University, Shenyang 110044, China \\ E-mail: ttkklltt@126.com \\ Jian Gui \\ School of Economics, Shenyang University, Shenyang 110044, China
}

\begin{abstract}
With the further development of market economy, small and middle enterprises have been the important support for the economic developments of various countries. However, the financing difficulty has largely contrasted with the important contribution of small and middle enterprises for the national economic development. As viewed from the course of the development of small and middle enterprises in the world, the financing difficulty of small and middle enterprises in the world has been a true fact. After the financial crisis broke out, the financing difficulty of small and middle enterprises is increasingly being deepened, and the governments of various countries have adopted multiple measures to deal with this problem. In this article, by analyzing the different financing modes adopted by US, Japan and Euro countries under the economic situation of financial crisis, the proper financing mode in the present economic environment is expected to be found for effectively solving the problem of financing difficulty for small and middle enterprises.
\end{abstract}

Keywords: Small and middle enterprise, Market economy, Financial crisis

\section{Small and middle enterprises financing modes of US in the financial crisis}

\subsection{Analysis of the development of small and middle enterprises financing modes of US}

US is the representative country which mainly adopts the direct financing mode, assisting with indirect financing mode. Because of the economic system and the developed securities market, US offers the platform of direct financing for small and middle enterprises. The US Small Business Administration controls the constitutions of macro control policies and the investments of civil capitals for small and middle enterprises, and the government only leads and supervises the financing of small and middle enterprises.

\subsubsection{Mode of direct financing}

(1) Direct financing companies. The direct financing mode of US means the investments by the direct financing companies, i.e. the venture capital companies, and the attention of these companies is to offer financing service for small and middle enterprise, and these companies can acquire the preferential loans below 90 million dollars from the federal government for the development and technical updating of small and middle enterprises. From 1958 to 2007, the investment amount to small and middle enterprises has exceeded 13 billion dollars, and the amount of small and middle enterprises which have obtained the investments has exceeded 100 thousands. The main investment target of the venture capital companies includes those small and middle enterprises which have the courage to technical innovation but lack in capital supports and loans. For the development of high-technical small and middle enterprises, the function of these venture capital companies is crucial.

(2) Securities financing. Except for the main market of securities trading, the capital market of US with the multi-layer and all-round securities market and the bonds rating mechanism has the NASDAQ market and the counter trading market which can offer large numerous of opportunities for small and middle enterprise. Because the listing standards are lower than the main board of the stock market and the listing conditions of the counter trading market are looser, most rising and growing companies choose to list in the NASDAQ market.

\subsubsection{Mode of indirect financing: loans from commercial banks}

The interior accumulation of small and middle enterprises of US occupies $25 \% \sim 85 \%$ in the long-term financing amount, and the proportion of commercial financing is not high, which is same with the financing of Chinese small and middle enterprises. The difference is that the mode that the US government leads the commercial financing institutions to loan to small and middle enterprise is to offer the guarantee funds by the policy financing institutions of small and middle enterprises. The US government only directly loan to those mall and middle enterprises with strong ability of technical 
innovation and good development foreground, so the loan volume is very limited.

\subsection{Analysis of the financing modes adopted by small and middle enterprises of US in financial crisis}

When the domestic banks of US are reluctant of lend for small and middle enterprises, the government adopts the financing mode of credit mortgage guarantee to support small and middle enterprise, and the original policies are frequently broke. To stimulate the small and middle enterprises of US and reduce the financing difficulty of trading of small and middle enterprises, and force the loan banks to provide more powerful supports for small and middle enterprises, the Export-Import Bank of Washington which is the import credit guarantee institution supported by the government recently integrated FTP and SDAP (Sustainable Development Action Plan) to make the total guarantee amount acquired by the loan banks in the original frame to achieve 0.45 billion dollars.

This measure of US means that after giving more financing conveniences for small and middle export enterprises, the new frame can not only help them to establish reasonable stock repertory system, but offer the risk control ability.

\section{Small and middle enterprises financing modes of Japan in the financial crisis}

\subsection{Analysis of the development of small and middle enterprises financing modes of Japan}

Japan is the first country which constituted the support policies for small and middle enterprises, and in the long-term process when small and middle enterprises of Japan could benefit from these support policies, the perfect small and middle enterprises financing mode including direct financing, indirect financing, and credit supplement has been gradually established.

\subsubsection{Mode of direct financing}

The capital cost paid by large enterprises for direct financing is far less than small and middle enterprises, and the proportion of direct financing in the exterior financing of small and middle enterprises in Japan is small. There are following sorts. (1) Venture capital companies. They are invested by the government, civil institutions and local institutions, and their responsibility is to invest capitals for small and middle enterprises specially. The venture funds publicly issues bonds to the society, which is guaranteed by the venture capital companies, and the venture capital companies also invest or loan to venture funds. (2) Civil risk investment companies. They are similar with the venture investment funds of US, and they are composed by banks, securities companies and guarantee companies. (3) The second board markets (counter trading market, JASDAQ market). The establishment of the second board markets of Japan could solve the financing difficulty for Japan small and middle enterprises.

\subsubsection{Mode of indirect financing}

The indirect financing mode not only occupies very important status in the whole financing mode of small and middle enterprises in Japan, but also is the main form of exterior financing for small and middle enterprises in Japan. The governmental financial institutions and the civil financial institutions compose the indirect financing system for small and middle enterprises in Japan. The institutions which capitals or debt guarantee are offered by the government is called as the governmental financial institutions, and these institutions don't accept saving in principle, but individual financial institutions also accept a few private capitals, but their main capital sources are from the government. To support the development of small and middle enterprises, Japanese government specially established three financial institutions serving for small and middle enterprises, i.e. the financial treasure of small and middle enterprises, the financial treasure of national life, and the central treasure of commerce and industry. These three governmental financial institutions are divided and complemented each other, and serve for small and middle enterprise from different angles and approaches of financing. The loan transaction is charged by the financial treasure of small and middle enterprises and the financial treasure of national life, and the securities investment, exchange trading and other diversified services are charged by the central treasure of commerce and industry, and its responsibility is same with other commercial banks. The cause that small and middle enterprises with bigger scale choose the financial treasure of small and middle enterprises is that the loans offered by this institution emphasize the demands of small and middle enterprises with bigger scale, but small enterprises lean to the financial treasure of national life, because this institution can provide small turnover capital loans to maintain the production. The civil financial institution is composed by two departments. The non-professional financial institutions are composed by the city bank, the local bank and the mutual bank. The bank which develops their businesses surrounding many big cities such as Tokyo, Nagoya and Osaka is called as city banks. The business of local bank spreads all over whole Japan, and it is closely related with small and middle enterprises and local governments in different regions. The mutual bank is the predecessor of the second local bank which was turned into the common bank in 1989, and its operation inherits the tradition of the mutual bank.

\subsubsection{Mode of credit guarantee}

To disperse the risk, the double-guarantee mode is adopted in Japan, and the credit guarantee of small and middle enterprises is first evaluated by the guarantee operation association. The guarantee association which takes the guarantee of credit financing activity sequence of small and middle enterprises as the aim saves the loans in the 
financial institutions, and promotes the increase of the guarantee loan businesses of small and middle enterprise by increasing the savings of financial institution. At the same time, the guarantee association requires the financial institutions to reduce the interest rate of guarantee loans by their savings in it.

\subsection{Analysis of the financing modes adopted by small and middle enterprises of Japan in financial crisis}

In the financial crisis, Japan used the mode combining the credit guarantee mode with the civil loan mode to relieve the financing difficulty of small and middle enterprises. The half-year report of Japanese policy financial treasure showed that because the business of its main operation object, small and middle enterprises, is deteriorated in the financial crisis, in the first half year after this financial institution is established, the loss of 6.68 billion dollars occurred. This financial treasure is the financial institution invested by the Japanese government. In the past term, to improve the financing status of small and middle enterprises, the government extended the credit guarantee system, and let the policy financial treasure to offer guarantees for the loans of small and middle enterprises. At the same time, to relieve the pressure of guarantee, Japanese government tried to promote the loans of civil financial institutions.

\section{Small and middle enterprises financing modes of Europe in the financial crisis}

\subsection{Analysis of the development of representative small and middle enterprises financing modes of Europe}

The financing mode of small and middle enterprises in Germany gives priority to the indirect financing mode, which is similar with the Japanese financing mode, but the proportion of interior financing of small and middle enterprises in Germany is bigger than the interior financing of Japan. Because of the occurrence of financial crisis after the World War II in Germany, large numerous of stocks of enterprises were forced to be purchased by commercial banks to commute bank loans, which further strengthened the association between banks and enterprises. Different with the "professional bank system" in other countries, the "universal bank system" of Germany is also called as the comprehensive bank system. German laws allowed commercial banks to deal with all financial activities in the securities market, such as offering the short-term commercial turnover loans, the middle and long-term loans of fixed assets, and the securities investments and entrusts. Because the operation range of commercial banks is wider, i.e. they can utilize the credit to create the stock options and the transaction of securities issue and securities underwriting, so only small space is leaved for the development of German securities market, and the banks which dominate the enterprises exist by the "universal" form. Contrastively, the German capital market with weak equity system is not developed, because the "universal" factor of banks makes enterprises more easily to obtain capitals from banks, and on the other hand, many problems such as higher cost, taxation and the opening of enterprise finance make enterprises would not to finance in the securities market.

The financing mode adopted by British is similar with US, and small and middle enterprises all depend on the developed capital market and financial market to finance. Because British government regulated that the securities issued by enterprises were limited by the lowest capital amount, so the proportion to issue capitals for financing is lower than US. The capital source of British small enterprises is mainly from two aspects, i.e. the own funds and the portfolios. Because the British government leads commercial banks and civil banks to invest for small and middle enterprises by the industrial investments with the public character, so the proportion of policy loan is very small.

\subsection{Analysis of the financing modes adopted by small and middle enterprises of Europe in financial crisis}

Since the beginning of 2009, many Europe large listed companies financed by increasing capital and stock or issuing bonds of small and middle enterprise to reply the financial crisis and solve the extremely urgency of seriously deficient own capitals. After the sign that the economy was stabilized just occurred, Europe stock markets rebounded universally, and enterprises showed strong financing desires to the financial market, so small and middle enterprises chose to finance in the market one after another. For example, in the last ten-day of March of 2009, British HSBC financed 14.5 billion Euros in the market by increasing issues in stocks, which is the largest single financing in Europe companies since this year. And the British Xstrata Group financed 4.4 billion Euros from the capital market in this year.

There are three important causes that Europe countries such as British and Germany adopted the debt financing and the equity financing. (1) Since the April of 2009, the stock market of Europe warms up, and there were about 60 large listed companied financed from the capital market according to relative statistics, and the financing speed of listed companies is quickening. (2) Investors' attitude has changed obviously, and in the initial of this year, the stock markets of Europe and US continued to descend following the depreciation tendency of last year, but when the stock markets warm up, the excessive pessimism emotion of the market has been changed largely, and investors though that the worst stage had already past, and they devoted capitals to the market again. Not only the stock market, but also other financial channels are changing, for example, the enterprise bond market is changed also, which is the good opportunity for small and middle enterprises to finance from the market. (3) Because banks universally frap loan conditions, so enterprises are more difficult to finance form the market. In the past two years, the loan conditions of Europe and US were relatively loose, and Europe enterprises accumulated mint debts, and to reduce the burden of loans and remedy the deficient capitals, Europe enterprises starved for flow capitals, so the financing in the stock and securities markets is possible and 
convenient, which can fulfill enterprises' demands for a great lot capitals.

In above analysis, because of the differences various national situations and the developments of small and middle enterprises in different countries, various countries certainly would adopt different financing modes. However, because of the uncertainty and high interest rate of civil financing and the non-normative character of financing mode, in the present economic situation, the financing of small and middle enterprises would get in larger difficulty. Therefore, the mode of civil financing is not applicable for small and middle enterprise in present economic environment. But with the information enhancement of the public to the financial market and the enhancement of the financial institutions and banks' mortgage risk control ability for small and middle enterprises, the equity \& bond financing mode and the mortgage guarantee financing mode can more effectively solve the financial difficulty for small and middle enterprises at the present stage.

\section{References}

Avery, R. \& Samolyk, K. (2000). Bank consolidation and the provision of banking services: The case of small commercial loans. Federal Deposit Insurance Corporation Working Paper.

De Young, R. Hunter, W.C. \& Udell, G.F. (2004). The past, present, and probable future for community banks. Journal of Financial Services Research. No.25. P.85-133.

Jin, Ling. (2001). Financing Model of Small and Middle Enterprises. Changsha: Master's Degree Thesis of Central South University of Technology. No. 1. P.3.

N. Berger, Gregory F. \& Udell. (1995). Relationship Lending and Lines of Credit in small Firm Finance. Journal of Business. No. 68(3). P. 351-381.

Sun, Zhixia. (2008). Study on the Development of Chinese Small and Middle Enterprises Financing Mode. Ji'nan: Master's Degree Thesis of Shandong University. No. 3. P.26.

Wang, Yong. (2003). Analysis of SME Financing Mode. Suzhou: Master's Degree Thesis of Suzhou University. No. 4. P.4. 